Наявного конфлікту інтересів немає. Джерела фінансування відсутні.

\section{Лiтература}

1. Максимов О. С. Методика викладання хімії у вищих навчальних закладах:Підруч. для студентів хім. спеціальностей вищих навчальних закладів I-IV рівнів акредитації. / О. С. Максимов Мелітополь, 2014. 91c.

2. Булгакова О. О. Використання ІКТ на уроках хімії та біології/ О.О.Булгакова// Таврійський вісник освіти. 2015. № 1. С. 103-108.

3. Юзбашева Г. С. Використання онлайн ресурсу для підвищення кваліфікації вчителів хімії/ Г. С. Юзбашева, С. В. Чхало // Організація освітнього процесу в закладах післядипломної педагогічної освіти 3 використанням електронних технологій навчання: методичні рекомендації / кол. авторів; за заг. ред. Л. Л. Ляхоцької; - К.: ДВНЗ «Ун-т менедж. освіти», 2017. - С. 131-145.

4. Семеріков С. О. Мобільне навчання: історико-технологічний вимір / С. О. Семеріков, М. І. Стрюк, Н. В. Моісеєнко // Теорія і практика організації самостійної роботи студентів вищих навчальних закладів: монографія / кол. авторів; за ред. проф. О. А. Коновала. - Кривий Ріг: Книжкове видавництво Киреєвського, 2012. - C. $188-242$.

\section{Надійшла: 08.10.2020}

Завершено рецензування: 02.11.2020

Прийнята до друку: 02.11.2020

DOI: $10.21802 / \mathrm{acm} .2020 .2 .8$

ОСОБЛИВОСТІ ПРОФЕСІЙНОГО СТАНОВЛЕННЯ СТУДЕНТСЬКОЇ МОЛОДІ

Н.В. Скробач, О.А. Шаповал, В.Ю. Вишиванюк, В.О. Петрина

Івано-Франківський національний медичний університет

scrobach1957@gmail.com

\title{
YOUTH PROFESSIONAL DEVELOPMENT
}

\section{N.V. Skrobach, O.A. Shapoval, V.Yu. Vyshyvanyuk, V.O. Petryna}

Ivano-Frankivsk National Medical University, Ivano-Frankivsk, Ukraine

E-mail: scrobach1957@gmail.com

Резюме. Професійна адаптація - це процес залучення підростаючого покоління до професійної діяльності, зумовлений правильністю вибору професії, рівнем професійної діяльності, а також характером професійної підготовки. Професійна адаптація розглядається як особливий вид соціального процесу, спрямована на те, щоб залучити до трудового життя суспільства групу людей, яка була штучно від цього життя відірвана на період навчання.

На формування професійної орієнтації впливає низка об'єктивних та суб'єктивних факторів. До об'єктивних факторів належать, перш за все, конкретні соціально-економічні умови, які будуть визначати місце особистості в системі виробничих відносин, а також характер праці, іiі стимулювання, умови праці, відносини в трудовому колективі. У сучасних умовах на ці фактори значною мірою впливають: економічна криза, безробіття, відсутність соціальної захищеності і водночас розширення міжнародних контактів, поява нових форм господарювання, впровадження інформаційних технологій і т. д. До суб'єктивних факторів слід віднести якості самої особистості, інтерес людини до змісту тієї чи іншої діяльності, почугтя задоволення цією діяльністю, цілі та мотиви, які стимулюють до цієї діяльності.

У період передадаптації відбувається практичне ознайомлення особистостіз новими обов' язками й вимогами зі сторони колективу та адміністрації, а також оцінки рівня підготовки особистості та іiі здатності виконувати професійні обов'язки. Тривалість цього періоду можлива від кількох місяців до року. На наступному періоді інадаптації особа виконує соціальну роль працівника, сприймає цілі та завдання організації та переходить до стабільної роботи. У період постадаптації активність працівника спрямовується на творче застосування накопиченого досвіду й знань у випадку позитивної адаптації.

Отже, об’єктивним критерієм професійної адаптації можуть бути успіхи в професійній діяльності, суб'єктивним - задоволення особи професійною діяльністю.

Ключові слова: студентська молодь, професійне становлення, адаптація, орієнтація, особистість. 
Abstract. Professional adaptation is a process of engaging young people in professional activity that is influenced by the right career choice, the level of professional orientation, as well as the type of professional training. Professional adaptation is considered as a special type of social process aimed at engaging the group of people in working life, as they were artificially disconnected from this life during their study.

The formation of professional orientation is influenced by several objective and subjective factors. The objective factors include specific socio-economic conditions that will determine the role of an individual in the system of working relations, as well as the nature of work, its stimulation, working conditions and working environment. Nowadays these factors are significantly influenced by economic crisis, unemployment, lack of social protection, as well as the expansion of international contacts, the appearance of new forms of employment, the introduction of information technologies, etc. The subjective factors include personality traits, the interest in performing the activity, the satisfaction from performing the activity, the motives and goals inducing this activity.

During the preadaptation period, an individual becomes acquainted with new duties and responsibilities that team members and the administration are expected of them to carry out; the individual's training level and their ability to carry out professional duties are assessed as well. This period can last from a few months to a year. During the next period of inadaptation, an individual assumes a social role of a worker, accepts the goals and tasks of the organization, and starts to carry out the planned tasks. In the period of post-adaptation, in case of positive adaptation, the employee's activity is aimed at creative application of the experience and knowledge acquired.

Thus, professional success can serve as the objective criterion for professional adaptation, while job satisfaction can be considered as the subjective one. To assess the results of professional adaptation, the adaptation levels, namely high, moderate, low, can be used.

Keywords: Students; Professional Development; Adaptation; Orientation; Personality.

Серед адаптаційних процесів провідне місце займає професійна адаптація, яка розглядається як особливий вид соціального процесу, спрямований на те, щоб залучити до трудового життя суспільства групу людей, яка була штучно від цього життя відірвана на період навчання. Професійна адаптація - це процес залучення підростаючого покоління до професійної діяльності, зумовлений правильністю вибору професії, рівнем професійної орієнтації, а також характером професійної підготовки [2, 3].

Зазвичай професійну адаптацію пов'язують з початком професійно-трудової діяльності людини, однак фактично вона починається значно раніше. У професійній адаптації, як процесі, ми виділяємо два основних етапи - підготовчий і безпосередній. Підготовчий етап професійної адаптації складається з таких періодів: вибору професії, професійної підготовки та працевлаштування.

Сполучною ланкою між сферами освіти й праці виступає період вибору професії. Вибір професії- основа самоствердження людини в суспільстві, одне з головних рішень у житті. Існують різні варіанти визначення поняття «вибір професії», однак всі вони містять думку, що професійне самовизначення представляє собою вибір, який здійснюється в результаті аналізу внутрішніх ресурсів суб'єкта вибору професії і співвідношення їх з вимогами професії [3].

Можна відзначити низку найважливіших обставин, які впливають на професійний вибір молоді. По-перше, це позиція старших членів родин, думка яких для молоді у сфері професійного вибору є визначальною. По-друге, це вплив однолітків (товаришів, друзів) i «значущих інших» із кола позасімейного спілкування (наприклад, вчителів, класного керівника та ін.). По-третє, це здібності та вміння молодої людини як суб'єкта діяльності, що є основою для формування іiї професійної придатності. По-четверте, це рівень побажань молодої людини. Недооцінювання чи переоцінювання своїх можливостей, а також завищення чи заниження бажань $є$ важливими регуляторами вибору професії. Окрім того - це неінформованість. Тут велику роль відіграє достовірність і доброякісність інформації, яка впливає на професійне майбутнє. І насамкінець - це схильність молодої людини до тих чи інших видів діяльності [7].

Не менш важлива роль упроцесі узгодженості обставин вибору професії повинна належати профорієнтації. Профорієнтація полягає в наданні допомоги особистості у використанні своїх власних особливостей, а також унаданні людині можливостей розвивати їх так, щоб вона могла обрати для себе галузі навчання і трудової діяльності в процесі життя, яке змінюється і - з одного боку- бути корисним суспільству, а з іншого - досягнути особистих прагнень.

На формування професійної орієнтації впливає низка об'єктивних і суб'єктивних факторів. До об'єктивних факторів належать перш за все конкретні соціальноекономічні умови, які будуть визначати місце особистості в системі виробничих відносин, а також характер праці, іiі стимулювання, умови праці, відносини в трудовому колективі. У сучасних умовах на ці фактори значною мірою впливають: економічна криза, безробіття, відсутність соціальної захищеності і водночас розширення міжнародних контактів, поява нових форм господарювання, впровадження інформаційних технологій і т.ін. До суб' єктивних факторів слід віднести якості самої особистості, інтерес людини до змісту тієї чи іншої діяльності, почуття задоволення цією діяльністю, цілі та мотиви, які спонукають до цієї діяльності $[1,4]$.

Заключним періодом підготовчого етапу професійної адаптації є працевлаштування. Сучасне працевлаштування випускників слід охарактеризувати як переважно індивідуальне, малоконтрольоване й вільне. В останні роки створюються фірми та організації, які надають допомогу населенню та молоді в працевлаштуванні, займаються збором та розповсюдженням інформації про вакантні місця та умови роботи.

Результатом періоду працевлаштування випускників вузу може бути:

1) працевлаштування за отриманою професією;

2) працевлаштування не за професією;

3) безробіття.

У період перед адаптації відбувається практичне ознайомлення особистості з новими обов'язками і вимогами зі сторонни колективу та адміністрації, а також оцінка рівня підготовки особистості та іï здатності виконувати професійні обов'язки. Тривалість цього періоду можлива від кількох місяців до року $[2,5]$.

Перші тижні та місяці роботи викликають великі труднощі в основному через неспівпадіння реального професійного життя з уявленнями та очікуваннями людини. Особливо це стосується молоді, яка пред'являє високі вимоги до умов праці, зарплатні і т.д., не маючи високої квалі- 
фікації та досвіду роботи. У цей період особа оцінює власну готовність до роботи, і за цими ж параметрами ії оцінює колектив та адміністрація закладу. Якщо ця оцінка збігається і є позитивною, то цей період можна вважати завершеним і відбувається перехід до наступного етапу. Якщо оцінка була негативною, то адаптація ускладнюється і можливий негативний результат, тобто звільнення [6].

У період адаптації особа виконує соціальну роль працівника, сприймає цілі й завдання організації і переходить до стабільної роботи. Від сучасного виробництва людина очікує задоволення не лише матеріальних потреб, але і можливості професійної самореалізації, підвищення кваліфікації, службового зростання,творчості, участі в суспільній та управлінській діяльності, спілкування 3 колегами і т.д.

У період постадаптації активність працівника спрямовується на творче застосування накопиченого досвіду та знань у випадку позитивної адаптації $[5,7]$.

Суб'єктивним критерієм професійної адаптації $\epsilon$ задоволення людини основними сферами праці (професійною, організаційною, соціально-психологічною, матеріально-побутовою), оскільки існує безпосередній зв'язок рівня професійної адаптації із задоволенням особистості. Чим вищий рівень адаптації, тим вищий рівень задоволеності.

До суб' єктивних показників адаптації в професійній сфері належать: рівень задоволення роботою, ії умовами й організацією, професією, можливостями підвищення кваліфікації і кар'єрного зростання, рівень задоволення матеріальною та моральною винагородою за працю, культурно-побутовими умовами та ін. В організаційній сфері суб'єктивними показниками є: рівень оцінки стану організаційної сфери, відповідність цієї оцінки дійсності, задоволення відносинами в організаційній сфері і т.ін. У соціально-психологічній сфері-це ступінь задоволення статусом у колективі, рівень оцінки якості колективуі т.д. У матеріально-побутовій - це задоволення зарплатнею і житлом, оцінка особистої матеріально-побутової забезпеченості і т.д. [2, 4].

Наступним рівнем, який розвиваючись може підняти пристосувальний процес, є етап взаємної терпимості. На цьому рівні як особистість, так і соціальне середовище проявляють взаємну терпимість щодо цінностей і форм поведінки.

Найвагоміший рівень адаптації - акомодація. Виникаючи на рівні терпимості, акомодація пов'язана з взаємними поступками. Це означає, що особа визнає основні цінності нового соціального середовища, а соціальне середовище у свою чергу, визнає деякі цінності особи. Високий рівень адаптованості характеризує найоптимальніше включення особистості в діяльність та спілкування. Середній рівень характеризується високим включенням особи в діяльність та спілкування, але зниженим рівнем емоційного самопочугтя. Низький рівень адаптованості особистості передбачає наявність задовільної виробничої активності і дисципліни, низьких оцінок соціометричного статусу й ступеня реалізації внутрішньо-особистісного потенціалу, перевагу престижно-особистісних мотивів у мотивації провідної діяльності, низький ступінь вираження колективістських мотивів, позитивну тональність індивідуального настрою, середній ступінь вираження синдрому психоемоційного настрою та високі показники ступеня вираження невротичних реакцій $[1,2,6]$.

Розглянувши рівні адаптованості особистості, можна стверджувати, що показником «позитивної» професійної адаптації $\epsilon$ підтримка такого рівня життя, який дозволяє зберігати чи підвищувати професійний та соціальний статуси й задовольняти матеріальні та духовні потреби особи $[2,4,5]$.

Узагальнюючи все вищесказане, можна зробити висновки, що професійна адаптація $є$ видом соціальної адаптації і займає провідне місце серед адаптивних процесів людини. Професійна адаптація - це процес залучення підростаючого покоління до професійної діяльності, обумовлений правильністю вибору професії, рівнем професійної орієнтації, а також характером професійної підготовки.

Професійна адаптація складається з двох основних етапів: підготовчого та безпосереднього. Підготовчий етап професійної адаптації складається $з$ таких періодів: вибору професії, професійної підготовки та працевлаштування, безпосередній етап професійної адаптації: етапи передадаптації, адаптації та постадаптації.

Об'єктивним критерієм професійної адаптації можуть бути успіхи в професійній діяльності, суб'єктивним - задоволення особи професійною діяльністю. Для оцінки результату професійної адаптації можуть використовуватись рівні адаптованості: високий, середній та низький.

\section{Література}

1. Срко AI, Тимощук АВ. Особистісно-професійне становлення фахівців в умовах вищого навчального закладу. Молодий вчений. 2017;12.1:64-67.

2. Кириченко ВВ. Психологічні основи професійної адаптації та вибору професії: навчальний посібник. Житомир: Вид-во ЖДУ ім. І.Франка; 2015. 110с.

3. Козирєв МП. Професійне становлення фахівця в умовах вищого навчального закладу. Науковий вісник. 2013;1:305-313.

4. Максименко СД, Філоненко ММ. Педагогіка вищої медичної освіти. Київ: Центр учбової літератури; 2014. 288c.

5. Олексіна НО, Волосовець ОП, П'ятницький ЮС. Медична освіта: відповідіта виклики сучасності. Медична освіта. 2018;2:3640. https://doi.org/10.11603/me.2414-5998.2018.2.8878.

6. Подковко ХВ. Інноваційні технології навчання в контексті компетентнісного підходу в освіті. Медична освіта. 2016;1;41-43. https://doi.org/10.11603/me.v0i1.6360

7. Філоненко ММ. Психологія особистісного становлення майбутнього лікаря: монографія. Київ: Центр учбової літератури; 2015.420c.

Received: 25.11 .2020

Revised: 07.12 .2020

Accepted: 09.12.2020 